\title{
METODE, SISTEM DAN PRINSIP \\ PEMBELAJARAN BAHASA ARAB YANG INOVATIF
}

\author{
M. Asy`ari \\ Institut Agama Islam Negeri (IAIN) Palu \\ Jl. Diponegoro No.23, Lere, Palu Barat, Kota Palu, Sulawesi Tengah 94221 \\ email: asyari1204@gmail.com
}

\begin{abstract}
Arabic is the second language used in Indonesia. Therefore, the good and appropriate methods, systems and principles of learning may certainly contribute to the achievement of the goals of Arabic language teaching and learning activities. When a teacher does not apply the methods, systems, and principles correctly, teaching will not be effectively directed. Today, there are many interactive and innovative Arabic learning models and techniques that can be applied by the teachers. The suitability of the application of methods, systems and principles will certainly increase the students' passion in learning Arabic simultaneously and continuously. The author has conducted a study of the existence of methods, systems and principles of Arabic learning that are considered the most effective. This type of research was descriptive research in which the researcher described the mechanism of a process. The innovative Arabic learning system are, among others, integrated systems, separation systems, and combined systems. While, the principle of innovative Arabic language learning is the principle of priority, the principle of accuracy, the principle of gradation, the principle of motivation, and the principle of validation. In the end, by combining these aspects, the purpose of learning Arabic will be achieved perfectly.
\end{abstract}

Keywords: methods, systems, principles, instruction, Arabic

\section{A. Pendahuluan}

Dalam kehidupan suatu bangsa, pasti mempunyai masing-masing bahasa, baik itu bahasa Indonesia, bahasa Arab, maupun bahasa Inggris. Keberadaan bahasa tersebut mempunyai peranan yang begitu penting untuk setiap masyarakat. Karena gambaran suatu negara atau bangsa tersebut mempunyai bahasa. Demikian juga dalam bahasa Arab, yang memiliki keistimewaan. Bahasa arab dijadikan sebagai firman Allah adalah karena sebagai penguatan untuk dapat memahami berbagai disiplin 
ilmu lainnya. Maka perlunya memahami hubungan antara bahasa Arab dan Al Qur'an. Sebab Al-Qur'an menggunakan bahasa Arab maka pada saat mengajarkannya pasti memerlukan kaidah-kaidah bahasa Arab, demikian pula sebaliknya. Hubungan bahasa Arab dan Al-Qur'an amat dikenal di seluruh dunia Islam. Bahasa Arab memang sebagai bahasa agama Islam meskipun tidak semua ummat Islam menggunakannya secara praktis. Patut dicatat bahwa orang Arab sangat berbangga dengan bahasanya, tidak terkecuali dengan mereka yang bukan muslim.

Dapat dilihat bahwa separuh warga Libanon adalah orang Kristen, mereka tetap menganggap bahasa Arab sebagai bahasa kebangsaannya. Demikian pula dengan Kristen Koptik di Mesir, suku Dinka Neur, dan Shilluk di Sudan, baik yang animis maupun yang kristen, semuanya menggunakan bahasa Arab demi kepentingan nasionalnya. ${ }^{1}$ Bahasa memiliki keistimewaan utama dalam kehidupan manusia dan telah dipelajari sejak zaman dahulu kala, khususnya bahasa keluarga yang diperlukan untuk berkomunikasi dengan orang sekelilingnya; Atau dengan kata lain untuk dapat hidup sebagai makhluk sosial maka bahasa adalah alat yang primordial dalam berkomunikasi.

Secara realita bahwa dalam Al-Qur'an dikatakan wa 'allama adam al asmaa kullaha, yang maksudnya kurang lebih bahwa Tuhan telah mengajar "bahasa" kepada Adam. Dalam belajar bahasa pada konteks tersebut, menurut Subyakto ${ }^{2}$ tidak ada yang dapat disebut sebagai guru dalam arti yang lazim, sehingga prosesi itu tidak dapat disebut "mengajar" bahasa. Mempelajari bahasa asing termasuk bahasa Arab, akan lebih sulit dipahami dibanding bahasa pertama.

\footnotetext{
${ }^{1}$ Hasyim Asy'ari, "Bahasa Arab dan Perkembangan Ilmu Pengetahuan" (Seminar Nasional Bahasa Arab, Universitas Gajah Mada Yogyakarta, 1988), h. 2.

${ }^{2}$ Sri Utari Subyakto, Metodologi Pengajaran Bahasa (Jakarta: Gramedia Pustaka Utama, 1993), h. 1.
} 
Dalam istilah yang sering digunakan dalam belajar bahasa yang bukan bahasa pertama atau bahasa ibu adalah belajar bahasa kedua atau bahasa asing. Dalam belajar bahasa Arab ini, diperlukan guru, artinya diperlukan adanya kegiatan belajar mengajar. Dalam proses belajarmengajar tersebut perlu dikembangkan cara atau metode yang biasa disebut dengan metodologi pengajaran bahasa asing. ${ }^{3}$ Istilah pemerolehan bahasa digunakan sebagai pembahasan tentang penguasaan bahasa pertama kali di usia anak-anak sebab pemrosesan itu didapatkan secara alamiah. Kemudian pemerolehan bahasa kedua dilakukan secara terencana, terstruktur dan dengan sadar.

Secara umum juga bisa dibandingkan dengan pendapat Anthony dalam Muljanto Sumardi, bahwa terdapat tiga term pengajaran bahasa yang harus difahami baik pengertian maupun konsepnya. Ketiga term tersebut adalah: pertama, pendekatan, yaitu sejumlah asumsi yang berkaitan dengan hakikat bahasa \& kegiatan belajar mengajar bahasa. Kedua, metode, yaitu keseluruhan rencana penyajian bahasa secara terstruktur berdasar pada suatu pendekatan yang telah diatur. Ketiga, tehnik, merupakan proses khusus yang diterapkan pada suatu kelas, bersamaan dengan pendekatan \& metode yang ditentukan. Jadi suatu pendekatan itu sifatnya aksioma (diterima sebagai kebenaran tanpa pembuktian), metode sifatnya prosedural, sedangkan teknik yang yang sifatnya operasional. ${ }^{4}$ Di dalam konteks pengajaran bahasa termasuk pengajaran bahasa Arab tidak dapat dikatakan ada suatu model dan

\section{${ }^{3}$ Ibid, h. 3-4}

${ }^{4}$ Anthony, dalam Mulijanto Sumardi, Pengajaran Bahasa Asing, Sebuah Tinjauan dari Segi Metodologi. (Jakarta: Bulan Bintang. 1975) h. 8-10, Lihat Juga A. Akrom Malibary Pedoman Pengajaran Bahasa Arab pada Perguruan Tinggi Agama Islam. (Jakarta: Depag RI.1976) h. 89-91 
metode yang lebih unggul dari yang lain, sebab setiap model dan metode memiliki landasan-landsan teoritis dan empiris.

Kaitan ini yang ada relevansinya dengan hal peningkatan membaca teks Arab, tentu ada motode pembelajaran yang lebih cocok dan inovatif. Mempelajari bahasa Arab memiliki perbedaan dengan bahasa pertama. Baik itu terkait metode, bahan atau materi bahkan langkah pelaksanaan pembelajarannya. Pada dasarnya setiap anak manusia memiliki kemampuan untuk menguasai setiap bahasa yang ada, meskipun dalam ukuran dan dorongan yang berbeda-beda. Di antara perbedaan tersebut yaitu tujuan pembelajaran yang hendak dicapai, kemampuan dasar yang dimiliki, motivasi, minat serta ketekunannya. ${ }^{5}$

Bahasa Arab sebagai bahasa internasional telah diakui oleh dunia. Tentu hal ini akan mempunyai peran yang signifikan dalam improvisasi dan kompetisi pada tingkat dunia internasional. Hal tersebut bukan saja dalam aspek perkembangan bahasa dan ilmu kebahasaan an sich, namun lebih dari hal itu. Yakni improvisasi pada aspek metodologi dan teknik pembelajarannya. ${ }^{6}$ Statement tersebut tentu dapat dibuktikan secara konkret dan faktual dalam kegiatan pembelajaran bahasa Arab. Dimana akhir-akhir ini banyak bermunculan model-model dan teknik pembelajaran bahasa Arab yang interaktif dan inovatif yang tentunya akan menambah gairah peserta didik dalam mempelajari bahasa Arab secara simultan dan berkelanjutan. Hal ini tentu harus disambut oleh para pendidik untuk direalisasikan secara aktif \& kreatif, sehingga proses pembelajaran bahasa Arab berlangsung maksimal \& terintegrasi dalam tujuan pembelajaran yang hendak dicapai.

\footnotetext{
${ }^{5}$ Lihat Abdul Aziz bin Ibrahim al-Ushaili. Psikolinguistik Pembelajaran Bahasa Arab, Terjemahan Oleh Jailani Husni, (Bandung: Humanora, 2009) Cet I, h. 101 -105

${ }^{6}$ Zulhannan, Teknik Pembelajaran Bahasa Arab Interaktif, (Jakarta ; Raja Grafindo Persada 2014) Cetakan I, hlm. 3
} 


\section{B. Pembahasan}

\section{a) Pembelajaran Bahasa Arab di Indonesia}

\section{Bahasa Arab Sebagai Bahasa Agama Verbalistik}

Dapat dipastikan bahwa masuknya bahasa Arab di nusantara bersama dengan masuknya Islam, sebab bahasa Arab begitu berkaitan dengan berbagai segi peribadahan dalam agama Islam disamping posisinya sebagai bahasa dari kitab suci umat Islam. Sebagai simbol ekspresi linguistik, pembelajaran bahasa Arab pertama kali di nusantara yaitu sebagai pemenuh keperluan primordial umat muslim saat menjalankan ritual beribadah seperti mendirikan sholat. ${ }^{7}$

Sesuai dengan kebutuhan tersebut, materi yang diajarkan hanya terbatas pada doa-doa shalat dan surat-surat pendek alQur'an yang lazim dikenal dengan juz 'amma. Metode yang lazim digunakan ialah metode abjadiyah ${ }^{8}$ yang terkenal dengan nama metode baghdadiyah (sekarang digantikan oleh metode Iqra'). Metode ini menekankan pada kemampuan membaca huruf alQur'an yang dimulai dari: (a) penyebutan huruf dengan namanya satu persatu dari alif sampai ya' secara abjad sampai murid hafal nama-nama huruf tersebut secara terpisah, kemudian (b) diajarkan kata-kata yang terdiri dari dua huruf , lalu tiga huruf, dan begitu seterusnya yang diberikan secara bertahap, kemudian meningkat pada: (c) pengajaran harakat, dimulai dengan menyebutkan huruf yang disertai dengannama harakatnya. ${ }^{9}$

${ }^{7}$ Ahmad Dardiri, Ta'lim al- 'Arabiyah fi Indonesia, (Jurnal Lingua Franca alJamiah Vol. I No. 12008 Pusat Bahasa UIN Syarif Hidayatullah) h. 125-130

${ }^{8}$ Ahmad Fuad Effendy, Metodologi Pengajaran Bahasa Arab, ( Malang: Misykat, 2005) h. 22

${ }^{9}$ Ibid, h. 23 
Pengajaran verbalistik tersebut terasa tidaklah mencukupi, sebab Al Qur'an tidak hanya untuk dibaca an sich (pada dirinya sendiri) sebagai media ibadah ritualistik, namun merupakan suatu pedoman yang harus dipahami makna dan diaplikasikan ajarannya.

\section{Bahasa Arab Sebagai Media Memahami Agama}

Pada bentuk kedua ini, pembelajaran bahasa arab mengalami perkembangan pada beberapa pesantren tradisional. Adapun materi yang disampaikan yaitu ilmu alat/ bahasa dan juga terkait dengan aqidah, fiqih, akhlaq, hadits dan tafsir. Sedangkan, metode pengajarannya dalam bentuk gramatika-tarjamah dengan teknik yang masih tradisional. Pengajarannya, dimana guru atau kiyai dan para murid (santri) masing-masing memegang buku (kitab). Guru membaca dan mengartikan kata demi kata atau kalimat demi kalimat ke dalam bahasa ibu atau bahasa daerah yang telah didekatkan kepada sensivitas bahasa Arab. Sedangkan tata bahasa (qawa'id) bahasa Arab diselipkan ke dalam kata-kata tertentu sebagai simbol yang menunjukkan fungsi suatu kata dalam kalimat. Santri hanya mencatat arti setiap kata atau kalimat Arab yang diucapkan artinya oleh guru, tanpa adanya interaksi verbal yang aktif dan produktif antara guru atau kiai dan santrinya. ${ }^{10}$ Diantara buku teks atau kitab yang merupakan karya Ulama yang biasa dipakai terutama dalam pengajaran bahasa Arab adalah Matan Aljurumiyah, Syarah Aljurumiyah, Kawakib Al-Durriyah, Alfiyah Ibnu Malik, Al-Sharf, Arudh al-Qawafiy, Jawahir al-Balaghah. 
Bentuk pengajaran bahasa Arab yang kedua ini merupaka hal yang seringkali dilaksanakan beberapa pondok pesantren di tanah air. Dan kontribusinya diakui sangat besar dalam memberikan pemahaman umat islam terhadap teks-teks keagamaan mereka. Namun, dipandang dari aspek komunikatif, kemahiran yang berhasil dicapai masih terbatas pada aspek reseptif. ${ }^{11}$

\section{Bahasa Arab Sebagai Media Komunikasi}

Pada bentuk ketiga ini sebagian besar pembelajaran bahasa arab siswa diarahkan kepada metode langsung. Masa belajar selama enam tahun yaitu setelah masa pendidikan dasar, bahkan lulusannya mampu berbahasa arab dengan baik secara tertulis ataupun secara lisan. Hal lain juga yang merupakan kemamampuan mereka yaitu dapat membaca dan memahami kitab berbahasa arab.

Seiring perkembangan zaman, belajar mengajar bahasa Arab pada perguruan islam modern tak hanya memakai metode langsung namun mengikuti pembaharuan yang ada di dunia pembelajaran bahasa, contohnya metode aural-oral (al-thariqah al-sam'iyah al-syafawiyah) dan pendekatan komunikatif (althariqah al-itthishaliyah). ${ }^{12}$

\section{b) Metode-Metode dalam Pembelajaran Bahasa Arab}

Dalam proses pembelajaran, pendidik hendaknya memiliki style dan seni mengajar, sehingga peserta didik tidak merasa bosan dalam mengikuti proses pembelajaran dan akan terjadi proses pembelajaran yang interaktif yaitu terjadinya komunikasi dua arah

${ }^{11}$ Ahmad Dardiri, Op. Cit. h. 133

${ }^{12}$ Lihat Ahmad F. Effendy dan Walfajri, Loc. cit. juga Ahmad Dardari Op. Cit. 
antara peserta didik dan pendidik secara aktif. Untuk merealisasikan hal tersebut, pendidik harus memberikan kesempatan kepada peserta didik seluas mungkin, menstimulus, serta memancing kreatifitas mereka dengan berbagai strategi pembelajaran bahasa Arab yang efektif dengan menggunakan beberapa Metode.

Sedangkan, metode pengajaran bahasa Arab modern adalah metode pengajaran yang berorientasi pada tujuan bahasa sebagai alat. ${ }^{13}$ Maksudnya, bahasa Arab dijadikan sebagai media komunikasi dalam berkehidupan modern, sehingga inti pembelajar bahasa Arab yaitu mampu menerapkan bahasa tersebut secara aktif dan mampu memahami ungkapan dalam bahasa Arab. Metode yang lazim digunakan dalam pengajarannya adalah metode langsung (tariqah almubasyirah). Munculnya metode ini didasari pada asumsi bahwa bahasa adalah sesuatu yang hidup, oleh karena itu harus dikomunikasikan dan dilatih terus sebagaimana anak kecil belajar bahasa. ${ }^{14}$ Ada yang beranggapan bahwa metode populer dan yang masih digunakan dalam belajar bahasa Arab, diantaranya:

\section{Metode Gramatika Tarjamah (الطريقة القواعد والترجمة)}

Metode ini merupakan gabungan antara metode gramatika dengan metode terjemah. ${ }^{15}$ Metode ini biasa juga diistilahkan dengan metode tradisional. Hal tersebut dikarenakan metode tersebut mengutamakan isi teks bahasa dan informasi terkait

${ }^{13}$ Muammad Abdul Qadir Ahmad, Thurqu Ta'lim al-Lughah al- 'Arabiyah, Cet. I, (Beirut Libanon: Al-Maktabah al-Amawiyyah, 1983) h. 5-8 lihat juga Hasan Ja'far alKhalifah, Fushul fi Tadris al-Lughah al- “Arabiyah, (Riyadh: Maktabah Rusydi, 2004) h. 17

${ }^{14}$ Rusydi Ahmad Thuaimah, Op. Cit. h. 610

${ }^{15}$ Disadur dari Mulijanto Sumardi, Pengajaran Bahasa Asing, Sebuah tinjauan dari Segi Metodologi. (Jakarta: Bulan Bintang. 1975) h. 37 Lihat juga Tayar Yusuf. Metodologi pengajaran Agama dan Bahasa Arab. Cet. I, (Jakarta: PT.Raja Grafindo Persada. 1995) h. 171 
kebahasaannya. Namun tak berarti bahwa metode inilah yang tertua. Term tradisional yang melekat pada metode ini, menurut Subyakto $^{16}$ lebih merupakan suatu pencerminan yang paling cocok dari cara beberapa bahasa Yunani kuno dan Latin yang telah diajarkan selama beberapa abad yang lalu.

Landasan teoritis dari metode gramatika terjemah ini adalah bahwa ada satu universal logic atau logika semesta yang termasuk dasar semua bahasa yang ada di dunia ini, dan bahwa tata bahasa adalah bagian logika dan filsafat. ${ }^{17}$ Jadi, belajar bahasa mampu memperkuat kemampuan berfikir secara logis, pemecahan masalah, dan kemampuan menghafal.

Memang, anak didik dengan menggunakan metode ini dituntut untuk menghafal teks kuno berbahasa asing dan terjemahannya dalam bahasa anak didik atau bahasa ibu, terutama teks-teks yang memiliki nilai sastra tinggi, meskipun pada teks tersebut seringkali ada susunan kalimat yang sulit dan kosakata atau sebuah ungkapan yang sudah tak dipakai. ${ }^{18}$

Metode ini tak memberi perhatian pada percakapan secara intensif dan anak didik cenderung pasif. Materi pelajarannya biasanya dari berbagai kitab nahwu (gramatika), kamus atau mufradat, dan teks bacaan. Dan hal yang begitu menonjol yaitu bahasa pengantarnya adalah bahasa ibu pelajar. ${ }^{19}$

\section{Metode Langsung (الطريقة المباشرة)}

Dalam bahasa Arab, metode ini dinamakan thariqah almubasyirah, yang muncul di Eropa sekitar abad ke 19 sebagai

\footnotetext{
${ }^{16}$ Sri Utari Subyakto, Op. Cit. h. 11

${ }^{17}$ Ibid. h. 12

${ }^{18}$ Lihat Azhar Arsyad, Op. Cit. h. 22-23

${ }^{19}$ Lihat Mukhtar al-Thahir Husain, Op. Cit. h. 221
} 
reaksi dan ketidakpuasan terhadap metode gramatika tarjamah. ${ }^{20}$ Asumsi metode ini bertentangan secara diametral dengan metode gramatika tarjamah. Asumsi dari metode langsung adalah bahwa proses pembelajaran bahasa Arab sama dengan pembelajaran bahasa ibu, yang berarti bahwa penggunaan bahasa tujuan/ asing harus dilakukan secara langsung dan intensif dalam berkomunikasi melalui mendengar dan berbicara. Sedangkan keterampilan membaca dan menulis dapat dikembangkan kemudian. Penggunaan bahasa ibu dihindari sama sekali (ibti'ad an lughah al-ummi) dan peserta didik dibiasakan berpikir dan praktiik dalam bahasa asing/ tujuan. ${ }^{21}$

Dengan demikian, dalam metode langsung, pengajar atau pendidik bahasa Arab langsung menggunakan bahasa tujuan/ asing ketika menjelaskan materi ajar dalam suatu proses pembelajaran dan bahasa persrta didik "haram" untuk dipergunakan. Menurut A. Fuad Effendi, salah satu pondok pesantren yang konsisten menerapkan metode ini adalah Pondok Modern Gontor Ponorogo. ${ }^{22}$

\section{Metode Membaca (الطريقة القراءة)}

Sama halnya dengan metode sebelumnya, kemunculan metode membaca ini juga merupakan reaksi dari metode langsung yang hanya memprioritaskan kemahiran berbicara dan kurang memberikan perhatian pada kemahiran membaca dan menulis. Atas dasar inilah, para pakar pendidik dan pakar bahasa termotivasi untuk mencetuskan sebuah gagasan metode

${ }^{20}$ Ibid, h. 230

${ }^{21}$ Ibid. h. 231

${ }^{22}$ Ahmad Fuad Effendy, Op. Cit. h, 39 
kontemporer sesuai dengan perkembangan pembelajaran bahasa pada waktu itu. Meskipun dinamakan metode membaca, tidak berarti bahwa bahwa proses pembelajaran terbatas pada latihan membaca an sich, latihan menulis dan berbicara juga diberikan kendatipun dengan porsi yang terbatas.

Tujuan utama metode ini adalah kemahiran membaca, yaitu agar peserta didik mampu memahami teks untuk keperluan studi mereka. ${ }^{23}$

\section{Metode Audiolingual (الطريقة السمعة والثفهية)}

Metode ini muncul dalam suasana Perang Dunia ke 2 di Amerika Serikat. Pada waktu itu diperlukan personalia yang lancer berbahasa asing untuk ditempatkan di beberapa Negara. ${ }^{24}$ Untuk keperluan tersebut, Departemen Pertahanan Amerika Serikat membentuk suatu badan yang bernama Army Specialized Training Program (ASTP) dengan bekerja sama 55 Universitas yang dimulai tahun 1943 dan betujuan agar peserta program dapat mencapai keterampilan berbicara dalam beberapa bahasa asing dengan pendekatan dan metode yang baru. Model ASTP tersebutlah yang kemudian menjadi cikal bakal dari Metode Audiolingual. Pada waktu yang bersamaan di Inggris juga dikembangkan Oral-approach yang sangat mirip dengan metode audiolingual. ${ }^{25}$

Asumsi metode ini adalah bahwa bahasa itu pertama-tama adalah ujaran dan kebiasaan. Oleh karena itu pengajaran harus dimulai dengan memperdengarkan bunyi-bunyi bahasa dan

${ }^{23}$ Ahmad Fuad Effendy, Op. Cit. h. 41

${ }^{24}$ Mukhtar al-Thahir Hasan, Op. Cit. h. 239

${ }^{25}$ Op. Cit. h. 46 
menjadikan bahasa sebagai kebiasaan dan harus diulang-ulang dengan teknik repetisi. Kegiatan bahasa harus diisi dengan dengan kegiatan berbahasa bukan mempelajari kiadah-kaidah bahasa. Tujuan utama metode ini adalah penguasaan empat kemahiran berbahasa secara seimbang dengan urutan penyajian menyimak dan berbicara baru kemudian membaca dan menulis. ${ }^{26}$

\section{Metode Komunikatif (الطريقة الأتصالية)}

Beberapa tahun kemudian setelah metode audio lingual mendapat kecaman dari para ahli dan praktisi muncullah metode komunikatif yang didasarkan atas asumsi bahwa setiap manusia memiliki kemampuan atau kompetensi bawaan yang disebut dengan "alat pemerolehan bahasa" (Language Acquisition Device/ $L A D)$. Oleh karena itu, kemampuan berbahasa bersifat kreatif dan lebih ditentukan oleh factor internal, sehingga relevansi dan efektifitas kegiatan pembiasaan dengan model latihan stimulus-respence-inforcment dipersoalkan. Asumsi berikutnya adalah bahwa penggunaan bahasa tidak hanya terdiri atas empat kemahiran berbahasa, akan tetapi mencakup beberapa kompetensi dalam kerangka komunikatif yang luas, sesuai dengan peran dari partisipan, situasi dan tujuan interaksi. ${ }^{27}$

\section{Metode Eklektik atau Campuran (الطريقة الإنتقائية)}

Metode eklektik atau metode campuran ini termasuk penggabungan dari unsur-unsur yang terdapat dari metodemetode sebelumnya terutama yang ada pada metode qawaid wat tarjamah \& metode mubasyirah. Metode ini memiliki asumsi bahwa tidak ada metode yang ideal, masing-masing memiliki

27 Ahmad Fuad Effendy, Op. Cit. h. 54-56 
kelemahan dan kekuatan; setiap metode mempunyai kekuatan yang dapat dimanfaatkan untuk mengefektifkan pembelajaran; tidak ada satu metode yang cocok untuk semua tujuan; yang paling vital dalam pembelajaran adalah memenuhi kebutuhan peserta didik; pengajar mempunyai wewenang untuk memilih suatu metode yang cocok dengan kebutuhan siswa. ${ }^{28}$

Bahasa Arab pada tingkatan Perguruan Tinggi, umumnya menggunakan metode eklektik. Ditambah lagi dengan kemajuan informasi dan teknologi dewasa ini terutama teknologi internet yang memudahkan orang mendapat akses informasi pembelajaran yang mutakhir dan terkini. Sebagai penguatan dalam penerapan metode maka diperlukan teknik Pembelajaran bahasa Arab. Sesungguhnya dalam setiap bahasa terdapat unsur-unsur yang dapat dilihat secara terpisah-pisah kendati antara yang satu dengan yang lain saling berhubungan erat sehingga terbentuk sebuah fenomena yang bernama bahasa.

Dalam unsur bahasa tersebut terdapat unsur tata bunyi atau al-ashwat (fonologi), kosa kata atau al-mufradat, tata kalimat atau al-nahwu, morfologi atau al-sharf, ataupun otografi (kitabah). Latihan unsur bahasa sangatlah vital bagi peserta didik. Karena ia merupakan partikulasi dari bahasa itu sendiri. ${ }^{29}$ Dalam penerapan metode pembelajaran bahasa Arab, terdapat beberapa teknik yang mendukung proses pembelajaran. Namun yang disajikan pada bagian ini adalah teknik pengajaran kemahiran berbahasa yang meliputi teknik pengajaran keterampilan menyimak, berbicara, membaca, dan menulis.

${ }^{29}$ Ahmad Fuad Effendy, Op. Cit. h. 81 


\section{c) Sistem dan Prinsip Pembelajaran Bahasa Arab yang Inovatif}

\section{Sistem Pembelajaran Bahasa Arab yang Inovatif}

Dalam pembelajaran bahasa, terdapat beberapa sistim, terpadu, terpisah-pisah, dan gabungan, sebagaimana telah dibahas sejarah muncul atau tumbuhnya pada sub bab terdahululu. Berikut dibahas gambaran umum system pembelajaran tersebut.

\section{a. Sistem Terpadu (نظرية الوحدة)}

Menurut Abdul Alim Ibrahim, bahasa merupakan kesatuan yang erat kaitannya dan bukan disajikan dalam bentuk separasi atau terpisah-pisah. ${ }^{30}$ Oleh karenanya, pada sistem ini hanya ada satu mata pelajaran, satu jam pertemuan, satu buku, satu evaluasi, dan satu nilai hasil belajar.

Adapun kelebihan dari teori ini adalah terletak pada landsan teoritisnya yang kuat, baik teori psikoligis, teori kebahasaan, maupun teori kependidikan. Adapun kelemahannya, jika diterapkan pada level perguruan tinggi kurang dapat mengakomodir pendalaman unsur bahasa atau keterampilan berbahasa tertentu yang memang menjadi kebutuhan nyata bagi para pebelajar bahasa. ${ }^{31}$ Sistem terpadu ini banyak diaplikasikan di beberapa sekolah menengah negeri yang ada di Indonesia.

\section{b) Sistem Separasi (نظرية الفروع)}

Sistem separasi merupakan kebalikan dari sistem terpadu. Dalam bahasa Inggris dinamakan separated system,

${ }^{30}$ Abdul Alim Ibrahim, al-Muwajjih al-Fanniy li Mudarris al_lughag al-'Arabiyah, (Kairo: Dar el-Ma'arif, 1962) h. 50

${ }^{31}$ Ahmad Fuad Effendy, Op. Cit. h. 80 
dalam bahasa Arab nizhamul furu'. Pada sistem tersebut, pelajaran bahasa terbagi menjadi beberapa mata pelajaran, contohnya mata pelajaran Nahwu, sharaf, muthalaah, insya' istima' muhadatsah, imla' khath, dan sebagainya. Setiap mata pelajaran memiliki silabus/ kurikulum, jam pertemuan, buku, evsluasi, dan nilai hasil belajar sendiri-sendiri. ${ }^{32}$

Kelebihan system ini adalah bahwa pendidik dan perancang kurikulum mendapatkan kesempatan yang cukup untuk memberikan perhatian khusus pada bidang kajian atau mata pelajaran tertentu yang menurut pandangannya sangat penting. Sedangkan kelemahannya adalah bahwa system ini mencabik-cabik keutuhan bahasa dan menghilangkan esensi serta watak alamiahnya. Hal ini menjadikan pengetahuan dan pengalaman kebahasaan peserta didik juga terpotong-potong, sehingga tidak mampu menggunakannya secara baik dan benar dalam kehidupan nyata. Pada sisi lain, system ini juga menyebabkan ketidakseimbangan antar berbagai unsur bahasa dan keterampilan berbahasa, baik pada proses pemebelajaran maupun output atau hasilnya. ${ }^{33}$

\section{c) Sistem Gabungan}

Sistem terpisah-pisah dalam pengajaran bahasa Arab digunakan di Pondok Pesantren dan Madrasah sampai tahun enam puluhan. Sedangkan sistem terpadu mulai diterapkan pada pertengahan tahun tujuh puluhan sampai saat ini. Namun terdapat pula lembaga pendidikan yang menggabungkan kedua system tersebut, misalnya di KMI Gontor yang

${ }^{32}$ Abdul Alim Ibrahim, Op.Cit. h. 51

${ }^{33}$ Ahmad Fuad Effendy, Op. Cit. h. 79 
menerapkan system integrasi selama satu tahun dan tahun berikutnya dengan system separasi. Ada juga Perguruan Tinggi yang menerapkan system integrasi tahun pertama (2 semester) dengan hanya 1 matakuliah Bahasa Arab dengan bobot 12 SKS; dan setelah itu baru disajikan secara terpisahpisah. $^{34}$

\section{Prinsip Pembelajaran Bahasa Arab yang Inovatif}

Permasalahan mendasar dalam pembelajaran bahasa arab bagi orang Indonesia yaitu berbedanya dilihat dari aspek bahasa pertama dan bahasa kedua. Karena hal tersebut terkait dengan perbedaan struktur kata dan kalimat yang ada dalam bahasa ibu dan bahasa target. Untuk mengatasi problematika tersebut perlu dicermati terkait berbagai prinsip yang dapat diterapkan dalam pembelajaran bahasa arab sebagai berikut:

\section{a) Prinsip Prioritas}

Prinsip ini secara mayoritas diterapkan pada sekolahsekolah modern dengan acuan sebagai berikut:

1. Latihan menyimak dan bercakap lebih diprioritaskan sebelum ditampilkan latihan membaca dan menulis.

2. Mengajar kalimat diprioritaskan sebelum mengajar kata.

3. Mengajarkan kosa kata yang berfrekuensi tinggi, lebih diprioritaskan walaupun mengandung unsur syaz atau mu'tal sebelum mengajarkan kosa kata yang lain.

4. Mengajarkan bahasa harus dengan kecepatan normal, seperti halnya penutur asli. ${ }^{35}$

\section{b) Prinsip Akurasi}

${ }^{34}$ Ibid. h. 81

${ }^{35}$ Hidayat, Op. Cit. h. 31 
Prinsip ini menekankan bahwa sejak awal peserta didik jangan dibiarkan berbuat kesalahan supaya tidak terbentuk kebiasaan berbahasa yang tidak tepat, baik dari aspek bunyi, struktur, maupun makna.

\section{c) Prinsip Gradasi}

Terminologi gradasi di sini mencerminkan bahwa:

1. Peserta didik diajarkan sesuatu mulai dari yang diketahui sampai yang belum diketahui, dari hal yang mudah menuju hal yang sulit.

2. Materi pelajaran yang disajikan mengacu pada materi yang lalu, baik dari aspek kosa kata, nahwu, sharaf, maupun makna. ${ }^{36}$

\section{d) Prinsip Motivasi}

Untuk merealisasikan prinsip motivasi ini, dapat ditempuh melalui langkah-langkah berikut:

1. Menghargai setiap jawaban peserta didik yang benar, dengan memberikan pujian.

2. Menumbuhkan semangat kompetitif di kalangan peserta didik.

3. Memasukkan unsur simulasi dalam aktifitas drill (latihan).

4. Menciptakan komunikasi edukatif yang harmonis antara pendidik dan peserta didik.

5. Memberi variasi dalam aktivitas pembelajaran.

\section{e) Prinsip Validasi}

1. Pembelajaran dilaksanakan secara praktik, bukan melalui penjelasan gramatika, khususnya bagi pemula. 
2. Penjelasan suatu makna kalimat dilakukan sedapat mungkin melalui hal-hal konkret, antara lain dengan menggunakan media visual. Gambar hidup dan realistik.

3. Pendidik memberikan pemahaman kepada peserta didik dengan cara merepetisi aneka contoh yang dapat dijelaskan melalui cara termudah dan lebih banyak kaitannya dengan arti yang berbentuk tulisan. Misalnya: jika pendidik mengajarkan isim, maka benda yang sebaiknya dijadikan contoh adalah kata-kata benda yang familiar dengan peserta didik dan yang ada di dalam kelas, seperti papan tulis, buku, polpen dan sebagainya. ${ }^{37}$

\section{Simpulan}

Dari uraian di atas, dapat penulis simpulkan bahwa pentingnya memahami metode pembelajaran bahasa arab dengan kesesuaian dengan berbagai sistem, dan prinsip. Menjadikan pembelajaran bahasa arab sangat menunjang dan membuka wawasan baru khususnya bagi pengajar bahasa arab. Karena dengan menggunakan metode, sistem, dan prinsip yang benar dan sesuai, maka guru akan mudah menyampaikan materi serta siswa juga dapat memahami materi yang diajarkan. Terlebih di Indonesia dengan adanya bahasa arab sebagai bahasa kedua bagi siswa, tentu metode, sistem dan prinsip haruslah diterapkan sesuai proporsinya. Dengan upaya tersebut harapan tercapainya tujuan pembelajaran bahasa arab, pasti akan mudah didapatkan.

${ }^{37}$ Lihat Zhulhannan, Op. Cit. 90 - 91, juga Mukhtar al-Thahir Hasan, Op. Cit. h. 


\section{Daftar Pustaka}

Asy'ari, H. (1988). Bahasa Arab dan Perkembangan Ilmu Pengetahuan. Makalah Seminar Nasional Bahasa Arab (hal. 2). Yogyakarta: Universitas Gajah Mada.

Banaamah, Adil Ahmad. (2014). Watsiqah Bina' Manhaj Ta'lim al-Lughah al-'Arabiyah Lighair al-Nathiqina Biha. Mekkah: Ummul Qura University.

Dardiri, Ahmad. (2008). Ta'lim al-'Arabiyah fi Indonesia. Jakarta: Jurnal Lingua Franca al-Jamiah Vol. I No. 1 Pusat Bahasa UIN Syarif Hidayatullah.

Effendy, Ahmad Fuad. (2005) Metodologi Pengajaran Bahasa Arab. Malang: Misykat.

Husain, Mukhtar Al-Thair. (2011) Ta'lim al Lughah al-Arabiyah Lighair alNathiqina Biha, fi Dhaui al-Manahij al-Haditsah. Makkah: al-Dar alalamiyah.

Husni, Jailani. (2009). Psikolinguistik Pembelajaran Bahasa Arab, Bandung: Humanora.

Ibrahim, Abdul Alim. (1962). al-Muwajjih al-Fanniy li Mudarris al-lughag al'Arabiyah, Kairo: Dar el-Ma'arif.

Malibary, A. Akrom. (1976). Pedoman Pengajaran Bahasa Arab pada Perguruan Tinggi Agama Islam. Jakarta: Depag RI.

Subyakto, S. U. (1993). Metodologi Pengajaran Bahasa. Jakarta: Gramedia Pustaka Utama.

Sumardi, Mulijanto. (1975). Pengajaran Bahasa Asing, Sebuah Tinjauan dari Segi Metodologi. Jakarta: Bulan Bintang.

Thuaimah, Rusydi Ahmad. (2010). al-Marja' fi Ta'lim al-Lughah al'Arabiyah. jilid 2. Mekkah: Jamiah Umm al-Qura.

Yusuf, Tayar. (1995). Metodologi pengajaran Agama dan Bahasa Arab. Cet. I. Jakarta: PT.Raja Grafindo Persada.

Zulhannan. (2014). Teknik Pembelajaran Bahasa Arab Interaktif. Jakarta: Raja Grafindo Persada. 